Medieval Studies, vol. 22, 2018 / Studia z Dziejów Średniowiecza, tom 22, 2018

\author{
Mariola Freza-Olczyk
}

(University of Gdańsk)

https://orcid.org/ 0000-0001-5088-9475

\title{
Bishop Conrad III of Kamień Pomorski: a common clergyman and a politician in the Duchy of Pomerania in 1233-1241
}

Keywords: Bischop Conrad III, Cistercian Order, Kamień Pomorski, Duchy of Pomerania

This essay presents the figure of Conrad Salzwedel, the bishop of Kamien Pomorski (1233-1241). The first objective is to describe briefly his origins and career history. After illustrating this general information relating to his personal life and his activity as a clergyman, the second part of this paper focuses on major documents and donations. The aim here is to portray Conrad III as a generous founder. Another essential point is to study his diplomatic relations with the Griffins, a dynasty from the Duchy of Pomerania. One of the points of this article is to outline the many conflicts Conrad Salzwedel had with other bishops. This is a complex problem which requires more consideration than is presented herein. The last part of this text examines the chief purposes of the agreement of 1240 between the bishop of Kamień Pomorski and the Pomeranian duke Barnim I.

Conrad III Salzwedel was born in the North March into a noble family which belonged to the free knighthood. His exact birth date is unknown, although scholars believe it was between 1170 and $1180 .{ }^{1}$

1 Albrecht Georg von Schwarz, Diplomatische Geschichte der Pommersch - Rugischen Städte Schwedischer Hoheit nach ihrem Ursprung, und erster Verfassung, nebst angehaugter Historie der Pommerschen Grafschaft Gützkow, 1755, pp. 714-715; E. Rymar, 'Wójtowie Salzwedel i hrabiowie Chockowa oraz ich pokrewieństwo z dynastia Gryfitów pomorskich,' Materiały Zachodniopomorskie, 27, 1981, pp. 236-237. Rymar bases his assertion about the year of Conrad's birth on the documents mentioned above from 1211 and 1241. Assuming that he had actually been chosen a canon 
After the margrave of Brandenburg, Albert the Bear, began his reign of the North March, the knighthoods were forced to become dependent on his authority. ${ }^{2}$

The Salzwedel family had been widely known since 1145. Additionally, some studies claim that members of this noble family had their own castle, and they served in offices of aldermen, but they remained vassal knights of Albert the Bear. Furthermore, a great number of them relocated to the Slavic borderland and established new counties. ${ }^{3}$ According to Gerard Labuda, Salzwedel referred to an old settlement complex where margraves from the Stade line removed their residence in $1057 .{ }^{4}$ Labuda also mentions that the name Saltwidele appears in about 1112 and that their territory had been settled by Germans as well as Slavs. ${ }^{5}$ Edward. Rymar's theory assumes there was a relationship in the second degree between Conrad III and Conrad I, the bishop of Kamien Pomorski from the twelfth century. It is worth noting that

in 1211, he might have been 30 years old. Moreover, according to the document from 1241 he was in poor health because of his old age, hence Rymar states that Conrad in all likelihood was 60 years old. If we assume this hypothesis, the bishop of Kamien Pomorski (north-western part of the Polish Pomeranian area) was actually born between 1170 and 1180.; idem, Rodowód ksiażat pomorskich, Szczecin 2005, p. 139; K.R. Prokop, Biskupi zachodniopomorscy (X-XX), Koszalin 2003, p. 54. In a document from 1211, bishop Conrad appears as 'Conradi de Saltwedele, canonicorum maioris ecclesie in Magdeburg,' see PU, I, no. 154. North March was a region of the Margraviate of Brandenburg in Germany. Bishop Conrad died on 20 September 1241. According to this document, he reached an advanced age: '[...] Conradus, comes in Gutzcova, episcopus s. ecclesiae Caminensis, per Decem annos ob. Debilitatem et senectutem alium in locum vocauit suum, utpote Wilhelmum doctprem theologiae insignem, deinde Gutzcovam in residentiam se contulit. Ibi anno MCCXLVIII placid decessit et corpus suum, exequiis solennibus Griphiswaldem translatum, a fratribus s. ordinis Francisci in cenobio ibidem sepultu' (see PU, I, no. 393).

2 The issue of his reign on the land of the North March is described in J. Hauziński, 'Cesarstwo Staufów a państwo zachodniopomorskie,' Rocznik Stupski 1986-1987, pp. 5-8. Conrad III, the first king of Germany of the Hohenstauf dynasty (1138-1152), ordered Henry the Proud, duke of Bavaria (1126-1138) to abandon Saxony and return the royal insignia. However, Henry refused his orders. Thereupon, Conrad III Hohenstauf gave Saxony (the greater part of North Germany) to Albert the Bear in 1138. Shortly thereafter Albert the Bear lost this land, and Conrad III had to relinquish the Duchy of Saxony in 1142 to Henry the Lion, a member of the Welf dynasty. The Saxon magnates returned the North March to Albert the Bear; E. Rymar, 'Wójtowie Salzwedel i hrabiowie...,' p. 237; K.R. Prokop, Biskupi..., p. 54. Albert the Bear was the Ascanian ruler who became the first margrave of Brandenburg in 1157; E. Rymar, Rodowód..., p. 139.

3 E. Rymar, 'Wójtowie Salzwedel i hrabiowie...,' p. 237; idem, Rodowód..., p.139.

4 They were members of the Saxon nobility.

5 G. Labuda, Fragmenty dziejów Stowiańszczyzny Zachodniej, vol. 3, Poznań 1975, p. 171. 
bishop Conrad III was presumably a grandchild of Conrad I. ${ }^{6}$ It was generally considered that bishop Conrad was a son of Frederick II, the alderman from Salzwedel (1177-1208) and an unnamed daughter of Jaxa, the Lutician duke from the twelfth century. ${ }^{7}$ What is more, Rymar underlines the relations between Frederick II and Albert II, who was the margrave of Brandenburg (1205-1220). Frederick II appears with his sons and margrave Albert II in a document from 1207. Members of the Salzwedel family are frequently present in margrave Albert's documents ${ }^{8}$ since Conrad III and his brothers were prominent figures. While Frederick III was the alderman in Salzwedel, another Jaxa was the founder of a county in Gützkow in 1235-1237. ${ }^{9}$

To comprehend the policy of bishop Conrad III it is crucial to analyse the beginnings of his career. According to sources, Conrad Salzwedel was initially a canon in Magdeburg between 1206 and 1233 . Meanwhile, he was promoted as a cantor in the Magdeburg chapter. ${ }^{10}$ The bishop of Kamien Pomorski is also mentioned in some of archbishop Albert's documents from 1225 to $1231 .{ }^{11}$ He also appears in the documents of archbishop Albert's half-brother, Wilbrand, who was the archbishop of Magdeburg. ${ }^{12}$

Nonetheless, the most significant issue is to identify the exact time when Conrad III assumed the position of bishop. This is essential to be able to describe his political activity, his actions as a spiritual leader, and,

6 E. Rymar, 'Wójtowie Salzwedel i hrabiowie...,' pp. 237-238. Conrad I was the second bishop in Pomerania (1160/1163-1186).

7 Regesten, no. 421 (1177), no. 439 (1181), no. 451 (1183), no. 463 (1188), no. 491 (1196), no. 532 (1207), no. 534 (1208); see E. Rymar, 'Wójtowie Salzwedel i hrabiowie...,' pp. 237-239 and ref. 13, p. 238. The Luticians were one of the Slavic tribes in the northern region of Germany.

8 Regesten, no. 544, p. 113. 'Fridericus iunior advocatus in Saltwitele' is mentioned in a document from 16 June 1209, and see Regesten, no. 550, p. 116. 'Conradus et Henricus de Saltwedele' appears in an agreement from 1212 between the margrave of Brandenburg and the Holy Roman Emperor Otto IV (1209-1215). For more see E. Rymar, 'Wójtowie Salzwedel i hrabiowie...,' p. 238 and PU, I, no. 158.

9 Gützkow was located in Mecklenburg-West Pomerania in Germany. From1235 Jaxa is mentioned as a witness in Conrad III's foundations, for example in a document from 1235 for the Cistercian Order in Doberan (in Mecklenburg-West Pomerania in Germany) (see PU, I, no. 316), in the foundation of 16 October 1235 of the collegiate church in Güstrow (see PU, I, no. 319, no. 320), and in the foundation of 1235 of the Cistercian Order in Dargun (see PU, I, no. 321).

10 PU, I, no. 154. Bishop Conrad appeared as a canon from Magdeburg in 1211; E. Rymar, Rodowód..., p. 139.

11 PU, I, no. 228 (1225), no. 238 (13 January 1227), no. 239 (13 January 1227), no. 261 (16 December 1229), no. 265 (26 March 1230), no. 275, (30 July 1231).

12 PU, I, no. 229 (30 January 1225), no. 240 (13 January 1227), no. 276 (31 July 1231), no. 296 (7 October 1233). 
subsequently, to establish the moment of the end of his reign. In the opinion of Tomasz Kantzow, Conrad III was a young count from Gützkow, and he became a bishop of Kamień Pomorski in 1233. The same date appears in other sources. A German chronicler suggests that Conrad III was indicated as the successor because of the predecessor, Conrad II. The previous bishop of Kamień Pomorski chose Conrad Salzwedel as a coadjutor before his death. ${ }^{13}$ The main reason for this decision is explained if we presume there was consanguinity between them..${ }^{14}$ In this case Conrad II's choice to elect Conrad Salzwedel as his successor is obvious. Nevertheless, Kantzow's theory is rejected by Rymar, who expresses doubts about the bishop of Kamien Pomorski and concludes that this assertion might be misleading because Conrad was a cantor of the Magdeburg chapter until 1233 and could not be a young count from Gützkow. ${ }^{15}$

As noted before, Conrad III was a generous founder through his donations to convents in Michaelstein, Doberan, Dargun, Kołbacz,

13 Pomerania oder Ursprunck, Altheit und Geschichte der Völcker und Lande Pomern, Caßuben, Wenden, Stettin, Rhügen in vierzehn Büchern beschrieben, vol. 1, ed. Hans Gottfried Ludwig Kosegarten, Greifswald 1816, p. 233, for information about choosing the next bishop of Kamień Pomorski by bishop Conrad II. See also T. Kantzow, Chronik von Pommern in hochdeutscher Mundart, vol. 2, ed. G. Gaebel, Stettin 1898, p. 101, ref. 1, which mentions the death of Conrad II in 1233. See also Pomerania. Eine pommersche Chronik aus dem sechzehnten Jahrhundert, vol. 1, ed. G. Gaebel, Stettin 1908, p. 203, for information about choosing the new bishop of Kamien Pomorski, Conrad III; PU, I, no. 299. A document from 1233 (October-November) has information about the death of Conrad II. His successor became the bishop of Kamien Pomorski at the end of 1233 (see PU, I, no. 301); see also T. Kantzow, Pomerania. Kronika pomorska $z$ XVI wieku, vol. 2, eds. T. Białecki, E. Rymar, Szczecin 2005, p. 325. In this the newest translation of the chronicle there is a passing remark about the death of Conrad II because of his great age and information about choosing Conrad III as his successor.

14 See Dtugossi seu Longini Canonici Cracoviensis Historiae Polonicae Libri XII, Joannis Dtugosz Senioris Canonici Cracoviensis Opera Omnia, ed. A. Przeździecki, vol. 11, lib. V-VIII, Cracoviae 1873, p. 60. John Długosz suspected that Jaxa belonged to the Griffin family; E. Rymar, 'Wójtowie Salzwedel i hrabiowie...,' p. 139 and ref. 24, p. 139. As mentioned previously, Conrad III's father, Frederick II, could have been married to the daughter of Jaxa of Köpenick, and this Jaxa conceivably belonged to the Griffin family (a dynasty of dukes from the Duchy of Pomerania); idem, Rodowód..., pp. 180-182. Conrad II was chosen as bishop on 3 May 1219 upon Pope Honorius III's recommendation. There is a probability that he was mentioned in documents from 1186-1189 as a provost, whereas in documents from 1191-1194 and 1208-1216 he is presented as a canon from Kamień Pomorski. Rymar asserted that Conrad II belonged to the offshoot of the Swantiborides (a branch of the Griffin dynasty), (see PU, I, no. 146 (1208)). He is probably mentioned as a witness in the document: 'Conradus prepositus et Bartholomeus et Kasimirus fratrem.' This could be evidence that he was a member of Swantiborides and was a son of Wartislaw II, the castellan of Szczecin and a regent in Western Pomerania in 1187.

15 T. Kantzow, Pomerania..., p. 325, ref. 157. 
Słupia, Eldena, and Grobia. He also made a foundation of the archdeaconry near the collegiate church in Ostrowo.

In 1233 Conrad III confirmed tithe rights for the Michaelstein convent. The lands granted were located in the western borderland of the diocese of Kamien Pomorski. Rosin, which is mentioned in the document, previously belonged to Nicholas and Henry from Rostock. ${ }^{16}$

In 1235 bishop Conrad III confirmed another tithe, this time for the Cistercian Order from Doberan which was situated in Mecklenburg-West Pomerania in Germany. Cistercians received villages such as Big Rakowo, Little Rakowo, and Przytyczna. ${ }^{17}$ Among the witnesses to this donation were duke Wartislaw III, ${ }^{18}$ Jakeze (Jaxa), the pantler (Latin dapifer) Jacob, ${ }^{19}$ Wargine, ${ }^{20}$ Stuzlaws, ${ }^{21}$ Paul,${ }^{22}$ Pribislav, ${ }^{23}$ and Albert. ${ }^{24}$

16 PU, I, no. 301. Nicholas and Henry were dukes from Rostock, which was situated in the Mecklenburg-West Pomerania in Germany. The Michaelstein convent was located in the diocese of Havelburg in Brandenburg, and the village of Rosin mentioned above was situated near Mecklenburg-West Pomerania in Germany.

17 PU, I, no. 316. Big Rakowo, Little Rakowo (Polish: Rakowo Wielkie, Rakowo Mate) and Przytyczna were located in the Łosice lands, which belonged to the diocese of Kamień Pomorski.

18 Wartislaw III was a duke of Pommerania-Demmin (1219-1264) and a cousin of duke Barnim I.

19 Jacob as a pantler from Kamień Pomorski is in the documents of duke Wartislaw III and in those of the previous bishop of Kamień Pomorski, Conrad II. See PU, I, no. 253 (1228), PU, I, no. 259 (1229), PU, I, no. 264 (1230-1232), PU, I, no. 378 (1240), PU, I, no. 406 (1242).

20 He is mentioned as a cupbearer in duchess Anastasia's document from 1224 (see PU, I, no. 222 (1224)) 'Wargine pincerna,' and then he is a castellan in the documents of duke Wartislaw III (see PU, I, no. 249 (1228), PU, I, no 253 (1228)). He appears in the document of the previous bishop, Conrad II (see PU, I, no. 283 (1232)).

21 Stuzlaws, tribunus (English: tribune) was an officer in medieval times and a castellan's deputy. He is mentioned as a tribune in a document of duke Wartislaw III (see PU, I, no 241 (1227), PU, I, no. 249 (1228), PU, I, no. 253 (1228), PU, I, no 272 (1231)). Then, he is mentioned as a castellan of Kamien Pomorski in documents of duke Warcislaw III and bishop Conrad II (see. PU, I, no. 283 (1232), PU, I, no. 378 (1240), PU, I, no. 387 (1241), PU, I, no. 406 (1242)).

22 Paul was an unknown Pomeranian nobleman. He appears in the documents of duke Wartislaw III (see PU, I, no. 237 (1227-1228), PU, I, no. 249 (1228), PU, I, no. 253 (1228)).

23 Pribislav was a lord from Kamień Pomorski. He appears in the documents of duke Casimir II and his son, duke Wartislaw III (see PU, I, no 165 (1215), PU, I, no 166 (1220), PU, I, no. 249 (1228), PU, I, no. 253 (1228)). See also E. Rymar, 'Zjazd w Kamieniu Pomorskim w końcu 1219 r. Świętoborzyce w ziemi choćkowskiej i kołobrzeskiej,' Materiaty Zachodniopomorskie, 22, 1976, p. 131.

24 Albert was a nobleman from Kamień Pomorski. He is mentioned as a witness in a document of duke Wartislaw III in 1228 and in a document of bishop Conrad III (see PU, I, no. 253 (1228) and PU, I, no. 387 (1241)). 
Bishop Conrad founded an archdeaconry near the collegiate church in Ostrowo (Güstrow) on 16 October 1235. He confirmed the Cistercian Order from Dargun ${ }^{25}$ the tithe rights to villages such as Bralin, Pynnow, Gholisowe, and Ducowe. ${ }^{26}$ In his next donation of 29 May 1236, Cistercians from Kołbacz received the tithe of Trzebież, Żelewo, Zdunowo, Wełtyń, Chlebowo, Przylep, Strzeblewo, Trzebień, Wysoka, Dobrepole, Zaborsk, Brody, and Kukinia. ${ }^{27}$ On 12 November 1237 Cistercians from Stolpe received the right of the patronage over the church in Szczytno. Conrad made this donation in remembrance of his brother Jaxa. ${ }^{28}$ The list of main witnesses includes representatives of many knightly families, such as the Behrs, the Berghes, and the Plesses, which became the future vassals of counts from Gützkow. ${ }^{29}$ Conrad III made the next donation on 14 February 1239 to the Cistercian convent in Dargun. ${ }^{30}$ In 1241 the bishop of Kamien Pomorski affirmed the ownership of four villages located near Gryfice and confirmed the tithe for the Cistercians from Eldena (Mecklenburg-West Pomerania). In the same year they received the tithe

25 Dargun was located in Mecklenburg-Western Pomerania in Germany.

26 PU, I, no. 319, no. 320, and no. 321. The village Pynnow was located near Stavenhagen (in Mecklenburg-West Pomerania) and was equated with the village of Gholisowe (also known as the village of Gulzow). The village of Bralin or Barlin belonged to the castellan of Demmin, Rochel. His son, Dobiesław, sold this village to the convent from Dargun in 1126 in order to honour his father's debts.

27 PU, I, no. 331. All villages were located in north-western Poland.

28 PU, I, no. 346 and no. 347. Stolpe was situated in the eastern part of Mecklenburg-West Pomerania in Germany.

29 E. Rymar, 'Wójtowie Salzwedel i hrabiowie...,' p. 241; K. Guzikowski, Obce rycerstwo na Pomorzu Zachodnim do poczatku XIV wieku, Szczecin 2013, pp. 168, 171-172. The list was extensive. Some witnesses came from noted families, for instance, Helmold von Plessen, a knight in the documents of bishop Conrad III (see PU, I, no. 319 (1235), PU, I, no. 320 (1235), PU, I, no. 346 (1237), PU, I, no. 383 (1249)), Lipold Behr from Mecklenburg, who is mentioned once in Barnim's documents and mainly in the documents of duke Wartislaw III (see PU, I, no. 476 (1248), PU, I, no. 478 (1248), PU, I, no. 492 (1249), PU, I, no. 498 (1249), PU, I, no. 499 (1249), PU, I, no. 514 (1250), PU, I, no. 536 (1251), PU, I, no. 538 (1251)), or Theodor Berg, who was a knight from Mecklenburg.

${ }_{30}$ PU, I, no. 363; see also J. Walachowicz, 'Dziesięcina biskupia na Pomorzu Zachodnim w okresie wczesnofeudalnym,' Czasopismo Prawno-Historyczne, 51, 1999, p. 167. Conrad III affirms regular payments to the church in Levin. According to Walachowicz, by this action the bishop was trying to save the church in Levin that was under Dargun patronage. 
of the village Dersekow. ${ }^{31}$ The last foundation was made on 8 March 1241 for the convent in Grobia. ${ }^{32}$

As was shown above, bishop Conrad was principally generous to the Cistercian Order. Presumably, this was a deliberate action, and, obviously, it was one of his goals to involve this convent in some economic affairs.

The another key point of this research is to explore in greater detail the political relationship between Conrad and the members of the Griffin family. Therefore, it is significant to examine further the political relations among margraves of Brandenburg (John I and Otto III) and dukes of Pomerania (Barnim I and Warcislaw III). ${ }^{33}$ Conrad III owed his position to the margraves because his family had been connected with Brandenburg for years. By the time he became the bishop of Kamień Pomorski, he is mentioned in many of margrave Albert II's documents. ${ }^{34}$

Undoubtedly, Conrad Salzwedel did not become a bishop accidentally. Additionally, Judith, the daughter of duke Mieszko III the Old, was the wife of Bernard III, who was a son of Albert the Bear. ${ }^{35}$ Then, duke Mieszko III had a daughter, Anastasia, from his second marriage, who was duke Barnim I's grandmother. The subsequent generations of the Griffin family as well as the Brandenburg generations of margraves had a common grandfather-duke Mieszko III. This fact possibly had a crucial impact in the future which led to the election of bishop Conrad. ${ }^{36}$ It is equally meaningful to study the fundamental reasons underlying the cooperation between Conrad III and the Pomeranian

${ }_{31}$ PU, I, no. 383. This document mentions villages such as Darsim (Ludwigsburg), Gubisteuitz (Gubistiwitz), and Guisdow (Gwizdoy) in the Ostrożeńska lands (see PU, I, no. 384). The Cistercian monastery in Eldena was in Mecklenburg-West Pomerania, and Gryfice was in north-western Poland.

32 PU, I, no. 387. Bishop Conrad III confirmed the tithe that was granted to the Norbertines from Grobia (near Usedom) by previous bishops of Pomerania (starting with the first bishop of Pomerania-Adalbert). This document mentions many villages such as Munuchowe, Secherina, Spacheviz, Sosnice, Dambagora, Rochowe, Gizin, Lipegora, Dolpowe, Clossowe, Bubaliz, Solathkewiz, Corene, Ribeniz, Rruene, Suelebe, Poplote, and Lochou.

33 Otto III (1220-1267) and John I (1220-1266).

34 Margrave Albert II (reign 1205-1220) was the father of John I and Otto III.

35 Mieszko III was a duke of Greater Poland from the Piast dynasty, and Bernard III was a count of Anhalt and a duke of Saxony in the twelfth and thirteenth centuries.

36 E. Rymar, 'Zaprowadzenie lennego zwierzchnictwa brandenburskiego nad księstwem Barnima I zachodniopo morskiego (1232-1235), in: Opuscula minora in memoriat Iosepho Spors, Słupsk 1993, pp. 119-120. 
dukes. Presumably, Conrad Salzwedel wanted to obtain Barnim's support during conflicts with adjacent dioceses. The period between 1217 and 1228 was a process of the subordination of the bishopric of Kamień Pomorski to the metropolis of Magdeburg. Nonetheless, this process encountered resistance in Kamien Pomorski. Pope Gregory IX (1227-1241) endorsed the direct subservience of the diocese of Kamien Pomorski to the Holy See in $1236 .{ }^{37}$ According to scholars, the authority of the archbishopric of Magdeburg was accepted by the bishopric of Kamień Pomorski from the reign of Conrad III Salzwedel. ${ }^{38}$ It was a period when the bishop had many disputes, for instance in 1236 with bishop Brunwart of Schwerin (Mecklenburg-West Pomerania in Germany), bishop Gernand of Brandenburg, and archbishop Fulko of Gniezno. ${ }^{39}$

37 B. Kumor, Z. Obertyński, Historia kościoła $w$ Polsce, vol. 1, part 1, PoznańWarszawa 1974, pp. 144-145; A. Wiencek, J. Rajman, Dzieje Kościoła w Polsce, Bielsko-Biała 2008, p.106.

38 E. Rymar, Biskupi-mnisi-reformatorzy. Studia z dziejów diecezji kamieńskiej, Szczecin 2002, pp. 18-19; M. Smoliński, 'Między dwoma organizmami państwowymi - biskup kamieński Herman von Gleichen i jego stosunki z książętami Pomorza Zachodniego oraz margrabiami brandenburskimi,' Średniowiecze polskie i powszechne, 3(7), 2011, p. 28.

39 E. Rymar, 'Między układem kremmeńskim i landyńskim (1236-1250). Wojna Pomorza Zachodniego z Rugią i Brandenburgia,' RH, 53, 1987, pp. 119-120; P. Nitecki, Biskupi Kościoła w Polsce. Stownik biograficzny, Warszawa 1992, pp. 162-163. According to academics, archbishop Fulko (1232-1258) owed his career to Kietlicz, the previous archbishop (1199-1219). Fulko held many provincial synods, for instance in 1233 in Sieradz (in central Poland) that were connected with nobles and duke Henry the Bearded (duke of Silesia and Poland in the first half of thirteenth century) plundering churches. The main idea of the synod from 1233 was to reform the rules concerning those who violate the properties of churches or cemeteries. Fulko acted as a liaison in the dynastic arguments. He had judicial and economic immunity in the interest of the church in Gniezno. In the meantime, he also obtained the privilege of carrying the metropolitan cross. K.R. Prokop, Arcybiskupi gnieźnieńscy w tysiacleciu, Kraków 2000, pp. 69-71; K. Śmigiel, Stownik biograficzny arcybiskupów gnieźnieńskich i prymasów Polski, Poznań 2002, pp. 36-39; see also E. Rymar, Klucz do ziem polskich, czyli dzieje Ziemi Lubuskiej aż po jej utratę przez Piastów i ugruntowanie wtadzy margrabiów brandenburskich, Gorzów Wielkopolski 2007, p. 60. Rymar claims that bishop Gernand of Brandenburg was trying to gain control of the lands of Teltow, Barnim (Brandenburg, Germany), and Wkrzańska (the region of Templin and Prenzlau in Germany). However, the margraves of Brandenburg refused him access to these lands. However, in 1237 they accepted tithe from them. Thereby, the margraves revoked the jurisdiction of bishop Conrad III on the territory of Wkrzańska. The reason for their decision is unknown. Rymar states that duke Barnim's second stay in Spandau (in Germany) in 1236 was related to this situation. Moreover, the bishop of Lebus (Brandenburg, Germany) complained to bishop Gernand of Brandenburg about the Lebus-Barnim borderland 
Conrad III lodged claims against Brunwart and Fulko to the Roman curia. He accused them of attempting to interfere in issues pertaining to his territory. According to Conrad, archbishop Fulko wanted to expropriate the land of Słupsk (in northern Poland) and subordinate this territory to Gniezno. The whole situation was interesting, and it absorbed the Pope's attention. ${ }^{40}$ Bishop Conrad III saw how to make use of this situation. Direct subordination to the pope was measurably more convenient than to the archbishopric of Gniezno. Apparently, bishop Conrad III was conscious of this fact, and he saw the profit that he could gain and the significant opportunity for the rapid expansion of the bishopric of Kamien Pomorski.

Marek Smoliński contends that a falsified document of 26 December 1237 terminated the dispute between Fulko and Conrad III. According to this academic, it was possible because duke Świętopełk gave Fulko villages such as Kruszewo, Mochle, and Orle. Some scholars claim that this arrangement was testimony to the building of an ecclesiastical jurisdiction and the reign of duke Świętopełk on the lands of Słupsk and Sławno, whereas others assert that this arrangement is evidence of an attempt to resolve misunderstandings between Fulko and Conrad III. Smoliński asserts that duke Świętopełk brokered a peace and all the Gniezno claims were dropped. ${ }^{41}$

On 7 September 1237 Pope Gregory IX assigned his legate Wilhelm from Modena to investigate the claims of both sides. This conflict was presented in the bulla of 20 March 1236. Wilhelm had to resolve the conflict among the bishops of Kamien Pomorski, Lebus, Meissen (Saxony, in Germany), and Bradenburg.

Unfortunately, there is no information about Wilhelm's ultimate verdict. In 1240 the ordinary from Kamień Pomorski sued the bishop

and complained to bishop Conrad III about the Kostrzyn-Kiniec borderland (between the Oder River and Lebus land).

40 J. Spors, Dzieje polityczne ziemi sławieńskiej, słupskiej i białogardzkiej w XII-XIV wieku, Słupsk 1973, pp. 100-101; K.R. Prokop, Biskupi..., pp. 57-58. Prokop claims that the argument about the affiliation of the diocese of the Castellany of Słupsk was connected with lands occupied by duke Świętopełk (duke of Eastern Pomerania in 1215-1266) at the cost of Western Pomerania, whereas other sources indicate the temporary subservience of the castellany of Słupsk to the jurisdiction of the archbishop of Gniezno. The castellany of Słupsk belonged formally to the bishopric of Kamien Pomorski. When duke Świętopełk subjugated this castellany, it passed under the authority of the Metropolis of Gniezno.

${ }^{41}$ M. Smoliński, Świętopetk Gdański, Poznań 2015, p. 216. Sławno, located in north-western Poland. Kruszewo, Mochle, and Orle are located near Nakło in north-central Poland. 
of Lebus for usurping territories of the Kamien Pomorski diocese. This complaint was mentioned in the bulla of 12 March 1240. During these conflicts, the Kamien Pomorski diocese lost the de Odera land that was probably the land of Kienitz (north-western Poland). According to some scholars, the argument between bishop Conrad III and the archbishop of Gniezno could have lasted until 1237. The main reason for this opinion is the fact that the papal bull from that year does not mention anything about this conflict. ${ }^{42}$ Officially, this political strife terminated in 1246 with an agreement: Kamien Pomorski obtained the Kienitz land, while Lebus obtained the Kostrzyn land. ${ }^{43}$ The problem of the administrative affiliation of the Kostrzyn and Kienitz lands was one of the most complicated matters. In 1235 bishop Henry of Lebus gave the Templars 200 acres by the Rurzyca River in north-western Poland (Cedyński castle). ${ }^{44}$ The bishop emphasized that if the lands were settled, rent would have to be paid to the church in Lebus. The main cause of this conflict stemmed from the fact that bishop Henry had confirmed the lands of duke Henry the Bearded as well as those founded by duke Barnim I. Consequently, bishop Henry had disposed of lands belonging to the diocese of Kamien Pomorski. This issue provoked Conrad III's outrage and initiated a period of counterclaims. ${ }^{45}$

42 J. Spors, 'Przynależność administracyjna ziem nad środkową Odrą i dolna Wartą (ziemi cedyńskiej, kinieckiej i kostrzyńskiej) w XII i w połowie XIII w.,' Ślaski Kwartalnik Historyczny Sobótka, 1, 1986, p. 6; see also K.R. Prokop, Biskupi..., p. 58, and M. Smoliński, Świętopetk..., p. 201.

$43 \quad$ J. Spors, 'Przynależność administracyjna ziem...,' p. 7.

44 See PU, I, no. 310.

45 J. Spors, 'Przynależność administracyjna ziem...,' pp. 9-12. According to Spors, the primary political and administrative affiliation of the land of Kienitz was unknown. In 1234 duke Henry the Bearded obtained the land of Kienitz. The affiliation of the land of Kienitz to the castellany of Lebus during the reigns of Silesian dukes was an obvious fact, while the period of the affiliation with Western Pomerania was quite arguable. The scholar assumes that it could have belonged to the castellany centre in Pyrzyce (north-western Poland). A similar situation was connected with the land of Kienitz. In 1218 duke Władysław III Spindleshanks (duke of Greater Poland in 1202-1229) acquired the castle town of Lebus with the whole castellany, but he lost these lands in 1225. Duke Henry the Bearded tried to regain his lost lands in 1225-1229. He attempted to get the eastern part of the castellany that belonged to duke Władysław III Spindleshanks. However, the land of Kostrzyn was probably under the reign of Władysław Odonic (duke of Greater Poland in 1229-1234). In 1234 the land of Kostrzyn was included with the western part of Greater Poland to Silesia, which lasted until 1250 (see also E. Rymar, Klucz do ziem..., pp. 54-55). Rymar claims that the northern borderlands of the land of Lebus with the land of Kostrzyn had been under the rule of duke Władysław Odonic since 1225. He asserts that in 1232 duke Odonic gave the Knights Templar 1,000 acres 
The episodes mentioned above could provide an explanation for why bishop Conrad attempted to gain some recognition from duke Barnim I. The agreement they made in 1240 was advantageous for both sides; ${ }^{46}$ the bishop of Kamien Pomorski gave the duke of the Western Pomerania a fief-rente. Duke Barnim obtained a tithe to 1,800 acres, whereas he granted Conrad III the district of Stargard with all appurtenances 'cum omnibus suis pertinenciis. ${ }^{47}$ This area was located near Płonia River that flows into Lake Dąie (in north-western Poland). Barnim was obliged to pay 26 marks annually (16 marks from Szczecin and 10 marks from Usedom). The bishop charged money from mints every year on 11 November, Saint Martin's Day. Furthermore, he obtained the right to mint coins and the right to collect duties and taxes from Cedynia, Penkun, and Prenzlau. ${ }^{48}$ Barnim emphasizes

from Chwarszczany and the castle town in Kostrzyn. In the same year the Templars gained another tithe from those lands from Lawrence II, the bishop of Lebus, who was also collaborating with duke Henry the Bearded. According to Rymar, duke Henry was an original donor, while duke Odonic only confirmed his donation. Then, in 1234, duke Henry subjugated the western part of Greater Poland. Duke Henry obtained the land of Eastern Lebus, Międzyrzecz (in western Poland), and the Pomeranian territory that was adjacent to the land of Kostrzyn alongside the lower Myśla River.

46 PU, I, no. 377.

47 Ibidem; R. Klempin, in PU, I, no. 453. The document contains the terms of the arrangement. Next to many villages we note places that are referred to with the term 'wiki', which denotes minor, peripheral settlements. Klempin localizes villages from donation: 340 acres from the wik of Princelaw (the village of Prenzlau located in north-east Germany), 100 acres from the village of Vrowini (a place located $8 \mathrm{~km}$ east of Prenzlau), 70 acres from the village of Bomgarde (located $7 \mathrm{~km}$ from Prenzlau), 60 acres from the village of 'Arnoldi de Valkenrede' (unidentified village), 60 acres from the village of Ludzlau (the village of Lutzlow located $15 \mathrm{~km}$ from Prenzlau), 60 acres from the village of Graningi (unknown village), 50 acres from the village of Samborii (located $17 \mathrm{~km}$ from the village of Gardziec), 150 acres from the wik of Pincun (the village of Penkun), 80 acres from Woldin (Wolin), 50 acres from the village of Wovezk (unknown location, maybe it was located near Penkun), 30 acres from Storcow (the village of Storkow was located $3 \mathrm{~km}$ from Penkun), 30 acres 'in alodio nostro,' 20 acres from the village of Prenzlau (located $8 \mathrm{~km}$ from Szczecin), 60 acres induabus villis Cristiani (unknown location, maybe near Szczecin), 20 acres from Pariglow (the village of Parigow located $10 \mathrm{~km}$ from Gardziec), 10 acres from the village of Celaeow (Zullckow, part of Szczecin), 30 acres from Wostow (the village of Gustrow located $5 \mathrm{~km}$ from Szczecin), 30 acres from Crecow (the village of Kreckow located $5 \mathrm{~km}$ from Szczecin), 150 acres from the wik of Szczecin, 150 acres from the wik of Pyrzyce, 50 acres in duabus villis Pribori (unidentified location, probably near Pyrzyce), 50 acres from Neulin (the village of Naulin located $4 \mathrm{~km}$ from Pyrzyce), 60 acres in duabus villis Zvantos (unknown location, maybe near Pyrzyce), 50 acres from Clodsin (the village of Kloxin located $15 \mathrm{~km}$ from Pyrzyce), and 100 acres from Usenam.

${ }_{48}$ Penkun in Mecklenburg-Western Pomerania in Germany. 
in the document that the main reason for his foundation was a token of a gratitude for bishop's contribution, '[...] Nos autem pro tantis beneficiis susceptis ab ecclesia Caminensi eidem ecclesie et episcopo suisque successoribus terram Starogard [...]. ${ }^{, 49}$

According to Jan M. Piskorski, the foundations of towns in the Duchy of Pomerania appeared at the same time as the reconstructions of villages. The purpose of this arrangement was to regulate some of the disputed issues that were connected with settlement. A document from 1240 regulates arguable questions associated with the tithe from many territories such as Prenzlau, Cedynia, Pyrzyce, Szczecin, and Penkun lands. ${ }^{50}$ The settlement of the Wkrzańska land was the most advanced. ${ }^{51}$ The arrangement from 1240 described peripheral settlements known as 'wiki' that were typical of Slavic settlement.

There is a presumption that the dominant reason behind Barnim's foundation was connected with financial aspects. The Kamien Pomorski bishop's primary aim was to build positive relations with duke Barnim I. As a result of this agreement, Conrad III Salzwedel received great benefits, and he was the actual winner in this contract. The Stargard land had a convenient, strategic location. As can be seen, the contemporaneous political situation in the Pomeranian Duchy as well as the historical situation had an immense influence on Barnim's decision. ${ }^{52}$

49 PU, I, no. 377.

50 J.M. Piskorski, Kolonizacja wiejska Pomorza Zachodniego w XIII i w poczatkach XIV wieku na tle procesów osadniczych w średniowiecznej Europie, Poznań 2005, p. 124

51 For further information see also W. Sommerfeld, Geschichte der Germanisierung des Herzogtums Pommern oder Slawien, Leipzig 1896, p. 148 et al., 163 et al. The Wkrzańska land appears in 1236 in a document about the Treaty of Kremmen. J.M. Piskorski, Kolonizacja wiejska..., pp. 124-125, ref. 21, p. 125.

52 K. Ślaski, 'Dzieje ziemi kołobrzeskiej do czasów jej germanizacji,' RTNT, 51, part 1, 1948, p. 50; J.M. Piskorski, Kolonizacja wiejska..., p. 124. According to scholars, the decision of duke Wartislaw III to sign the Treaty of Kremmen on 20 June 1236 was significant. He recognized the lordship of margrave John I and Otto III over his duchy. The Ascanians gained new tributary, and it was surely helpful in achieving influence over the lands of Barnim I. Duke Wartislaw III had to submit to the overlordship of the margraves of Brandenburg, and he had to ceded the lands of Stargard, Wustrow, and Beseritz to them. This agreement was especially unprofitable for the duke Barnim. If duke Wartislaw III were to die childless, his lands would pass to Brandenburg. In this case, the whole of the Demmin land (Mecklenburg-Western Pomerania, in Germany) would become the property of margrave John I and Otto III. This episode probably had colossal influence on the future decisions of duke Barnim. Perhaps, because 
Another significant subject of this paper is the relationship of bishop Conrad III with the Knights Templar. Some scholars attempt to explain the main reason duke Barnim I founded lands for the Templars. Obviously, the primary motivation was to protect the borders of his lands against invaders. However, this fact raise another question regarding the originator of this idea. ${ }^{53}$

Paweł Stróżyk proposes a theory about the relationship between the Templars and the Salzwedel family and bishop Conrad III which connects this theory with Jaxa, who was linked with the foundation of the preceptory in Tempelhof. Stróżyk asserts that Jaxa might have had a connection with the Salzwedel family through the marriage of Frederick Salzwedel to Jaxa's cousin, which was why he gained Köpenick. ${ }^{54}$ Thereafter, Jaxa granted the rulers of Western Pomerania

of this, in 1240 he signed an arrangement with bishop Conrad III. Barnim was trying to minimize risk from the invader so he reinforced his diplomatic contacts with bishop Conrad, who was indebted to the margraves. Duke Barnim definitely had a limited budget because of many wars and conflicts, so he had to find another way to enlarge his property. The agreement from 1240 was an excellent idea for reaching this goal. Most of all, this agreement was profitable for bishop Conrad III because it marked the beginning of the building of the bishop's dominion over Pomeranian lands. Presumably, duke Barnim was anticipating support from the bishop in his problems with margraves. However, he could only expect his neutrality. Conrad did not want to go against his benefactors. G. Labuda, Historia Kaszubów na tle historii Pomorza, vol. 1, Gdańsk 2006, p. 155.

53 J. Spors, 'Geneza i początki brandenburskiego zwierzchnictwa lennego nad Pomorzem Zachodnim na tle rywalizacji o ziemie nad środkową Odrą i dolną Wartą w latach 1234-1261,' Studia nad wczesnośredniowiecznymi dziejami Pomorza Zachodniego, XII - pierwsza połowa XIII wieku, Słupsk 1988, pp. 301-302. Spors claims that Thegeno and Hermannus were Templars, but they came from the order in Tempelhof; K. Bobowski, 'Czy datowanie zwierzchnictwa Brandenburgii nad Pomorzem Zachodnim przed 1250 rokiem jest uzasadnione,' Ślaski Kwartalnik Historyczny Sobótka, 66, 1990, p. 509. Bobowski asserts that the Thegeno and Hermannus sacerdotes were Templars from Western Pomerania, probably from Chwarszczany; P. Stróżyk, 'Fundacja preceptorii templariuszy w Tempelhof,' RH, 58, 1992, pp. 5-22. Stróżyk agrees with Schultze in saying that Herman came from Tempelhof. Two documents for the Templars were signed in Spandau, and this fact could testify to the association with the preceptory from Tempelhof; E. Rymar, 'Zaprowadzenie lennego zwierzchnictwa...,' pp. 129, 137 ref. no. 42. Rymar claims that they came from the land of Banie; E. Burzyński, Zakon rycerski templariuszy na ziemiach Polski piastowskiej i na Pomorzu Zachodnim, Wodzisław Śląski 2010 p. 87. The scholar asserts that Thegeno and Herman were Templars from the commandry located in the village of Rurka.

54 J. Bieniak, 'Polska elita polityczna XII wieku (Część III A. Arbitrzy książąt — krag rodzinny Piotra Włostowica)', Społeczeństwo Polski Średniowiecznej. Zbiór studiów, red. S.K. Kuczyński, Warszawa 1990, vol. 4, p. 75 n. 103; see also P. Stróżyk, 'Fundacja preceptorii...,' p. 20. 
rights to succession in the Köpenick Duchy. ${ }^{55}$ According to Stróżyk, because of this the Salzwedel family gained the castellany of Gützkow under feudal law. Jaxa's lack of any descendants meant that the Salzwedel family obtained all rights to the preceptory of Tempelhof. What is more, Stróżyk highlights the connections among Jaxa, the alderman from Salzwedel, and the descendant of Frederick Salzwedel with duchess Dobrosława, who was a sister of a Pomeranian duke. ${ }^{56}$

Rymar claims that there was a probability that bishop Conrad I and his brother John were descended from the Salzwedel family. ${ }^{57}$ The scholar believes that bishop Conrad I was a brother of Jaxa from Köpenick, who is mentioned in the documents of bishop Conrad III. Additionally, the scholar also emphasizes the similarity between names. Jaxa had a son born in 1218-1220 whose name was John, whereas bishop Conrad I had a son with the same name. ${ }^{58}$ This could lead to the conclusion that the Knights Templar were some kind of liaison between the bishop of Kamien Pomorski, his family, and duke Barnim I. In 1233 Conrad Salzwedel became a bishop and just a year later duke Barnim I started his foundations for the Templars. Three donations for this order were made in the 1230s. Conrad III was a bishop until 1241, while Jaxa died in 1237. After this time, Barnim I made only one foundation in 1244 for the Knights Templar. It was his last document for this order.

After Conrad III's death in 1241 there was a casual vacancy in the bishopric of Kamien Pomorski. ${ }^{59}$ In 1244 in Lyon the pope in a bulla instructed Conrad the bishop of Meissen to engage the problem of the election of the subsequent bishop, Wilhelm.' He appears on 22 February 1246 as a bishop elect and a witness to Barnim's document for the Cistercian Order in Dargun. On 13 January 1247 Wilhelm is mentioned as the next bishop of Kamien Pomorski. ${ }^{60}$

This essay shows that bishop Conrad III administrated in the period of conflict between the archbishoprics of Magdeburg and Gniezno. Conrad III had to choose the side of Magdeburg because of his relations with the margraves. The complaint that he made against

55 J. Bieniak, 'Polska elita...,' p. 107; see also P. Stróżyk, 'Fundacja preceptorii...,' p. 20 .

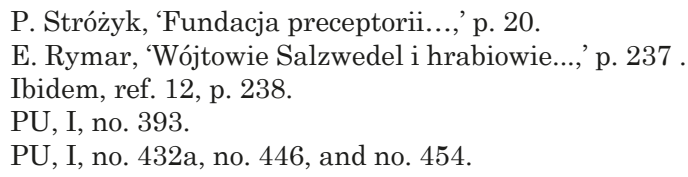


archbishop Fulko to Pope Gregory IX could be a sign of his submission. The time of his reign was also linked with a period of Germanization in the duchy of duke Barnim I. Additionally, it is fairly plausible that the ancestry of Conrad Salzwedel had also some influence on bringing the Knights Templar to the lands of Western Pomerania in the thirteenth century.

The most significant achievement of the bishop was the agreement of 1240 that provided the Stargard land. Bishop Conrad III was conscious of how to take advantage of the contemporaneous political situation in the lands of duke Barnim I, who had numerous arguments and conflicts that required immense financial contributions. Not long after when Wilhelm I became the next bishop of Kamien Pomorski, the agreement from 1240 led Barnim I to contribute another donation for the local church in 1248. This treaty provided the eastern part of the land of Kołobrzeg (located in West Pomerania in Poland) to the bishopric of Kamien Pomorski. ${ }^{61}$ Bishop Conrad III obtained the rights to the Stargard land that had a crucial strategic location.

61 E. Rymar, 'Wojny na Pomorzu Zachodnim i wojenne czyny Pomorzan poza Pomorzem XII-początek XVII wieku (Kalendarium),' in: Pomorze militarne XII-XXI w., part I, eds. K. Kozłowski, E. Rymar, Szczecin 2004, pp. 145-146. The period of 1233-1236 was difficult for duke Barnim I and duke Wartislaw III with the Danish-Mecklenburger aggression in 1233 and then another invasion by Denmark, Rugen, and Mecklenburg in 1235-1236. The Pomeranian dukes also must have been aware of duke Świętopełk. In 1238 unidentified Germans attacked Santok (in western Poland) under the leadership of Władysław Odonic. Among these, Germans scholars have identified Barnim warriors. In 1240-1245 the Duchy of Pomerania participated in the war with Brandenburg (see also PU, I, no. 475). 